Tương tự, nghiên cứu của Đào Ngọc Phức (2017) tại viện Nhi TW cho thây $26,6 \%$ điều dưỡng sau khi bị bạo hành y tế muốn thay đổi nơi làm việc, $76,1 \%$ giảm hiệu suất làm việc [2]. Do đó, các bệnh viện cần có các sinh hoạt nghề nghiệp phù hợp, giúp các đối tượng đã bị bạo hành duy trì và nâng cao tình yêu nghề nghiệp, tránh tình trang bỏ nghề sau khi bị bạo hành. Bên cạnh đó, nghiên cứu của Đỗ Mạnh Hùng (2018) chỉ ra rằng mối quan hệ không tốt với người bệnh và người nhà người bệnh là yếu tố nguy cơ bị bạo hành ở điều dưỡng viên $(p<$ 0,01)[1]. Trong nghiên cứu này, $95 \%$ điều dưỡng viên trả lời họ ước mình đã được đào tạo về phòng tránh bạo hành tại nơi làm việc. Như vậy, việc tập huấn, đào tạo các kỹ năng để xây dựng mối quan hệ với người bệnh cũng như phòng tránh bạo hành cho điều dưỡng viên có thể là biện pháp can thiệp hữu ích giúp giảm bạo hành tại khoa phòng.

\section{KẾT LUÂ̂N}

Sau khi bị tấn công, 90\% điều dưỡng viên cảm thấy lo lắng về tình trạng bạo hành tại nơi làm việc. Bên cạnh đó, tác động của trải nghiệm bạo hành tại nới làm việc tới điều dưỡng viên bao gồm: Thường xuyên nhớ lại lúc bị tấn công $(87,5 \%)$; Cố tránh suy nghĩ hay nói chuyện về việc bị tấn công (75\%); Lo sợ mình lại bị tấn công trong tương lai (90\%); Cực kỳ cảnh giác, chuẩn bị phòng vệ trong lúc làm việc $(90 \%)$; Có cảm giác không yêu nghề như xưa $(75 \%)$; Uớc mình đã được đào tạo về phòng tránh bạo hành tại nơi làm việc (95\%).

\section{TÀI LIÊU THAM KHẢO}

1. Đỗ Mạnh Hùng, Lưu Thị Mỹ Thục, Phạm Thu Hiên (2018). Môt số yếu tố ảnh hưởng đến bao hành nơi làm việc bằng lời nói do khách hàng gầy ra đố với điều dưỡng viên tại các khoa lâm sang bệnh viện Nhi TW. Tạp chí Y học thành phố Hồ Chí Minh, 22(6).

2. Đào Ngoc Phức. Thực trang bao hành bênh viện đối với đ̛uêuu dưỡng viên và một số yếu tố ảnh hưởng tại bệnh viện Nhi Trung ương năm 2017. Luận văn thạc sỹ quản lý bệnh viện, Đại học Y tế công cộng.

3. Groenewold, M. R., Sarmiento, R. F. R., Vanoli, K., Raudabaugh, W., Nowlin, S., \& Gomaa, A. (2017). Workplace violence injury in 106 US hospitals participating in the occupational health safety network (OHSN), 2012-2015. American Journal of Industrial Medicine, 61(2) 157-166

4. Rukiye Pinar, Firdevs Ucmak (2011). Verbal and physical violence in emergency departments: a survey of nurses in Istanbul, Turkey. Journal of clinical nursing, 20(3-4):510-7

5. Spector, P. E., Zhou, Z. E., \& Che, X. X. (2014). Nurse exposure to physical and nonphysical violence, bullying, and sexual harassment: A quantitative review. International Journal of Nursing Studies, 51(1), 72-84.

6. Yuan Yang, et.al, Workplace Violence Against Chinese Frontline Clinicians During the COVID-19 Pandemic and Its Associations With Demographic and Clinical Characteristics and Quality of Life: A Structural Equation Modeling Investigation. Front Psychiatry. 2021; 12: 649989.

7. Zhang S, Liu ' $\mathbf{W}$, Wang $\mathbf{J}$, et al. Impact of workplace violence and compassionate behaviour in hospitals on stress, sleep quality and subjective health status among Chinese nurses: a crosssectional survey BMJ Open 2018;8: e019373. doi: 10.1136/bmjopen-2017-019373.

\title{
KẾT QUẢ CHĂM SÓC NGƯờI BÊNH SAU MỔ GÃY XƯƠNG CHI DƯỚI TẠI KHOA NGOẠI BỆNH VIỆN TRUNG ƯO'NG THÁI NGUYÊN
}

\section{Mai Thị Vân Hằng ${ }^{1}$, Nguyễn Đình Phúc ${ }^{2}$, Lê Hải Yến ${ }^{1}$}

\section{TÓM TẮT}

Mục tiêu: Đánh giá kết quả chăm sóc người bệnh (NB) sau mổ gãy gãy xương chi dưới tại khoa ngoại bệnh viện Trựng ương Thái Nguyên. Đối tượng: 166 NB được phẫu thuật gãy xương đùi và xưởng cẳng chân tại khoa Ngoai chấn thương chỉnh hình bênh viên Trung Ương Thái Nguyên từ tháng 10 năm 2020 đến

${ }^{1}$ Trường Cao đẳng Y tế Thái Nguyên
${ }^{2}$ Trường Đại hoc Thăng Long Hà Nội.

Chịu trách nhiệm chính: Mai Thị Vân Hằng

Email: vanhang119@gmail.com

Ngày nhận bài: 6.8.2021

Ngày phản biên khoa hoc: 4.10 .2021

Ngày duyệt bài: 13.10 .2021 tháng 04 năm 2021. Kết quả: Nguyên nhân gãy xương do tai nạn giao thông chiếm 72,9 \%, gãy kín chiếm $71,1 \%$. Gã̃y thân hai xương cẳng chân chiếm tỷ lệ 38,6\%. Trong 24 giờ đầu sau mổ, đau vừa $68,7 \%$, đau nhiều chỉ chiếm 19,2\%. Thời điểm ra viện các mức độ đau giảm dần. Tình trang vết mổ khô bình thường chiếm 98,2\% Người bệnh ăn uống bình thường $(97,0 \%)$, được tập nhẹ các ngón chân $(98,8 \%)$. Kết quả chăm sóc NB sau mổ, tâi thời điểm 24h có $96,3 \%$ Người bệnh có tình trạng phẫu thuật tốt chiếm 93,3\%. Không có trường hợp nào có tình trạng xấu sau phấu thuật

Tư khóa: gãy xương, chi dưới, gãy xương chi dưới, khoa ngoại, bệnh viện.

\section{SUMMARY}




\section{RESULTS OF CARE OF PATIENTS SURGERY FOR LOWER LIMB FRACTURES AT SURGICAL DEPARTMENT OF THE THAI NGUYEN NATIONAL HOSPITAL}

Objectives:To evaluate of the postoperative care for patients after surgery for lower limb fractures at the surgical department of Thai Nguyen National Hospital. Subjects: 166 patients underwent surgery for femur and shin bone fractures at the Department of Orthopedic Surgery at Thai Nguyen Central Hospital during the study period from October 2020 to April 2021. Results: The main cause of fractures was traffic accidents accounting for $72.9 \%$, closed fractures accounted for $71.1 \%$. Fracture of two shin bones accounted for the highest rate of $38.6 \%$. In the first 24 hours after surgery, most patients had moderate pain $(68.7 \%)$, severe pain only accounted for $19.2 \%$. At the time of discharge from the hospital, the pain levels gradually decreased. Normal dry wound condition accounted for a high rate $(98.2 \%)$, patients slept well (99.4\%). The patient ate normally (97.0\%). In terms of movement, the majority of patients lightly exercise their toes (98.8\%). Results of patient care after surgery, at $24 \mathrm{~h}, 96.3 \%$ of patients had good surgical condition and when discharged from hospital, most of the patients were in good condition after surgery, accounting for $93.3 \%$. There were no cases of bad condition after surgery.

Keywords; fracture, lower limb, lower limb fracture, surgical department, hospital.

\section{I. ĐẶT VẤN ĐỀ}

Gãy xương chi dưới là môt chấn thương thường gặp trong ngoại khoa và phổ biến ở Việt nam.. Thông thường một trường hợp gãy hở cẳng chân nếu tiến triển tốt cũng mất tám tháng đến một năm để lành xương. Có những trường hợp nhiễm trùng quá nă̆ng phải cắt bỏ cẳng chân, gây tàn phế suốt đời. Hiện nay với sự phát triển mạnh mẽ của $Y$ học, việc điều trị gãy xương cũng có nhiều phương pháp từ bảo tồn đến phẫu thuật để trả lại chức năng bình thường cho người bệnh. Những trường hợp gãy không vững, gãy thấu khớp, gãy hở, gãy di lệch nhiều, bó bột thất bại không thể điều trị bảo tồn thì cần chỉ định phẩu thuật mổ kết hợp xương. Bên cạnh các phương pháp điều trị, việc chăm sóc của điều dưỡng viên đóng góp một phần quan trọng. Việc chăm sóc NB đã được quy định tại Thông tư 07/2011/TT-BYT[2]. Công tác chăm sóc sau mổ đúng quy trình như theo dõi, thay băng vết mổ, dùng thuốc, hướng dẫn tập luyện phục hồi chức năng sau mổ... giúp NB hồi phục nhanh chóng. Đã có nhiều đề tài nghiên cứu về đặt điểm lâm sàng và kết quả trong điều trị gãy xương, nhưng rất ít đề tài nghiên cứu về công tác chăm sóc điều dưỡng. Như nghiên cứu của Đào Đức Hạnh (2015) tại Bệnh viện Trung ương Quân đội 108, mới chỉ đề cập đến quá trình chăm sóc cho NB chấn thương cấp I, trong đó có nhiều chỉ số chăm sóc NB được đánh giá còn chưa thực hiện đầy đủ [6]. Tại các bệnh viện Thái Nguyên cũng rất hạn chế. Vì vậy, nghiên cứu này được tiến hành với mục tiêu: Đánh giá kết quả chăm sóc người bệnh sau mổ gãy gãy xương chi dưới tại khoa ngoại bệnh viện Trung ương Thái Nguyên.

\section{II. ĐỐI TƯỢNG VÀ PHƯƠNG PHÁP NGHIÊN CỨU}

2.1. Đối tượng nghiên cứu: Gồm 166 bệnh nhân được phẫu thuật: gãy xương đùi và xương cẳng chẩn và được chăm sóc điều dưỡng theo qui trình nghiên cứu

* Tiêu chuẩn lựa chọn

+ NB gãy xương đùi, xương cẳng chân được chỉ định phẫu thuật.

+ Từ 10 tuổi trở lên.

+ Không phân biệt giới tính.

+ Được chăm sóc điều dưỡng theo qui trình ngiên cứu

* Tiêu chuẩn loại trừ

+ NB gãy xương do các nguyên nhân khác (u xương, lao xương...).

+ NB/người nhà người bệnh không đồng ý tham gia nghiên cứu.

\subsection{Phuong pháp nghiên cứu:}

2.2.1. Thiết kế nghiên cứu: Nghiên cứu mô tả loạt trường hợp, tiến cứu

2.2.2. . Cỡ mấu: Chọn mẫu thuân tiên, có166 NB thỏa mãn các tiêu chuẩn lựa chọn.

\subsection{Biến số nghiên cứu}

- Đặc điểm nhân khẩu học: tuổi, giới, nghề nghiệp, nơi sinh sống, trình độ học vấn, nguyên nhân gây tai nạn...

- Tình trạng bệnh:nguyên nhân phải phẫu thuật, phương pháp điêu trị, hình thái, tính chất gãy xương...

- Kết quả chăm sóc người bệnh sau mổ:

+ Theo dõi toàn trang sau mổ:dấu hiệu sinh tồn, chảy máu sau mổ, đau sau mổ, tình trạng vêt mổ, dẫn lưu.

+ Các họat động chăm sóc người bệnh sau mổ: Dinh dưỡng; Vệ sinh; Tâm lý, tinh thần; Tập vận động, phục hồi chức năng; Tư vấn, GDSK khi ra viên.

2.4. Địa điểm nghiên cứu khoa ngoại bệnh viện Trung ương Thái Nguyên.

2.5. Phương pháp xử lý số liệu Bệnh án nghiên cứu, được mã hóa theo phần mềm Epidata 3.1. Và xử lý theo phương theo phần mềm SPSS 20.0

2.6. Đạo đức nghiên cứu; Nghiên cứu được thông qua đề cương NC, Hội đồng đạo đức của Bệnh viện và được người bệnh chấp thuận. 


\section{KẾT QUẢ NGHIÊN CỨU}

3.1. Thông tin chung. Tổng số có 166 bệnh nhân, nam giới $64,5 \%$ ) Có $54,2 \%$ NB có trình độ học vấn là $\mathrm{THPT}$, cao đẳng $(8,4 \%)$, đại học và sau đại học chiếm chỉ chiếm $2,4 \%$. NB bị gãy xương chủ yếu là do tai nạn giao thông $(72,9 \%)$, tai nạn sinh hoạt $(24,7 \%)$, tai nạn lao động $(2,4 \%)$. Về đặc điểm gãy xương, gãy thân hai xương cẳng chân $(38,6 \%)$, gãy đầu trên, dưới xương đùi $(31,9 \%)$ vàgãy thân xương đùi $(29,5 \%)$, gãy kín $(71,1 \%)$. NB được mổ mổ phiên chiếm tỷ lệ $62,7 \%$, mổ cấp cứu $37,3 \%$. Sử dụng nẹp vít AO/DHS chiếm 40,4\%, đinh nội tủy $30,1 \%$, thay chóm là $24,7 \%$ chỉ có $4,8 \%$ là cố định ngoài. Có tới 99,4\% NB được sử dụng phương pháp vô cảm gây tê tủy sống.

3.2. Kết quả chăm sóc người bệnh sau mổ Bảng 3.1. Tri giác và chí số sinh tồn

\begin{tabular}{|c|c|c|c|c|}
\hline \multicolumn{2}{|c|}{ Nô̂i dung } & 24h đâu; n (\%) & Ngày 5 n (\%) & Ra viện n (\%) \\
\hline \multirow{3}{*}{ Ý thức } & Tiếp xúc tốt & $166(100)$ & $166(100)$ & $166(100)$ \\
\cline { 2 - 5 } & Kích thích vật vã & $0(0)$ & $0(0)$ & $0(0)$ \\
\cline { 2 - 5 } & Lơ mơ & $0(0)$ & $0(0)$ & $0(0)$ \\
\cline { 2 - 5 } & Hôn mê & $0(0)$ & $0(0)$ & $0(0)$ \\
\hline \multirow{2}{*}{ Huyết áp } & Bất thường( cao) & $41(24,7)$ & $13(7,8)$ & $13(7,8)$ \\
\cline { 2 - 5 } & Bình thương & $125(75,3)$ & $153(92,2)$ & $153(92,2)$ \\
\hline \multirow{2}{*}{ Mạch } & Bất thường (nhanh) & $7(4,2)$ & $0(0)$ & $0(0)$ \\
\cline { 2 - 5 } & Bình thường & $159(95,8)$ & $166(100)$ & $166(100)$ \\
\hline \multirow{2}{*}{ Nhịp thở } & Bất thường (nhanh) & $5(3,01)$ & $1(0,6)$ & $0(0)$ \\
\cline { 2 - 5 } & Bình thương & $161(96,9)$ & $165(99,4)$ & $166(100)$ \\
\hline \multirow{2}{*}{ Nhiệt độ } & Bất thường(cao) & $8(4,8)$ & $4(2,4)$ & $0(0)$ \\
\cline { 2 - 5 } & Bình thương & $158(95,2)$ & $162(97,6)$ & $166(100)$ \\
\hline
\end{tabular}

Tại thời điểm 24h đầu sau mố, toàn bộ NB tỉnh tiếp xúc tốt (100\%), không có NB lơ mơ, kích thích vật vã và hôn mê; $24,7 \% \mathrm{NB}$ có huyết áp cao hơn giới hạn bình thường; 4,2\% NB có mạch nhanh. Sau 3 ngày và khi ra viện tất cả NB đều bình thường.

Bảng 3.2. Tình trạng đau sau mổ

\begin{tabular}{|c|c|c|c|}
\hline Nội dung & 24h đâuu n (\%) & Ngày 5 n (\%) & Ra viện n (\%) \\
\hline Không đau & $0(0,0)$ & $2(1,2)$ & $145(87,3)$ \\
\hline Đau nhẹ ít & $22(13,2)$ & $98(59,0)$ & $13(7,8)$ \\
\hline Đau trung bình & $114(68,7)$ & $66(39,8)$ & $8(4,8)$ \\
\hline Đau nhiêu & $30(19,2)$ & $0(0)$ & $0(0,0)$ \\
\hline
\end{tabular}

Phần lớn NB trong 24 giờ đầu sau mố đau vừa chiếm tỷ lệ cao nhất có $(68,7 \%)$, đau nhiều $(19,2 \%)$, đau nhe ít $(13,2 \%)$. Mức độ đau giảm dần sau 3 ngày và̀ khi ra viện.

\section{Bảng 3.3. Tình trạng vêt mố}

\begin{tabular}{|c|c|c|c|c|}
\hline \multicolumn{2}{|c|}{ Nội dung } & 24h đầu n (\%) & Ngày 5 n (\%) & Ra viện n (\%) \\
\hline \multirow{4}{*}{$\begin{array}{c}\text { Tình trạng } \\
\text { vết mổ }\end{array}$} & Khô bình thường & $160(96,3)$ & $143(86,1)$ & $163(98,2)$ \\
\cline { 2 - 5 } & Sưng nề đỏ & $153(92,2)$ & $19(11,4)$ & $3(1,8)$ \\
\cline { 2 - 5 } & Tiết dịch & $1(0,6)$ & $13(7,8)$ & $0(0)$ \\
\cline { 2 - 5 } & Chảy máu & $6(3,6)$ & $0(0)$ & $0(0)$ \\
\cline { 2 - 5 } & Toác vết mố & $0(0)$ & $0(0)$ & $0(0)$ \\
\hline
\end{tabular}

Phần lớn vết mố của NB trong 24 giờ đâu sau mô khô bình thường chiếm tỷ lệ cao nhất $157(94,6 \%)$, sưng nề đỏ là $153(92,2 \%)$, chảy rỉ máu là $6(3,6 \%)$. Khi ra viện chỉ còn $1,8 \%$ NB có vết thương sưng nề đỏ.

\section{Bảng 3.4. Chât lượng giấc ngủ}

\begin{tabular}{|c|c|c|c|}
\hline Nội dung & 24h đâu n (\%) & Ngày 5 n (\%) & Ra viện n (\%) \\
\hline Ngủ bình thường $(>6 \mathrm{~h})$ & $77(46,4)$ & $159(95,8)$ & $165(99,4)$ \\
\hline Ngủ vừa $(2 \mathrm{~h}-6 \mathrm{~h})$ & $75(45,2)$ & $9(5,4)$ & $1(0,6)$ \\
\hline Ngú ít, Không ngủ được $<2 \mathrm{~h}$ & $14(8,4)$ & $0(0)$ & $0(0)$ \\
\hline
\end{tabular}

Trong 24 giờ đầu sau mố NBngủ được bình thường (46,4\%), Ngủ ít hoặc không ngủ $(8,4 \%)$; Sau 3 ngày NBngủ bình thường là $95,8 \%$; Thời điểm ra viện là $99,4 \%$.

\section{Bảng 3.5. Tình trạng vận động}

\begin{tabular}{|c|c|c|c|}
\hline Nội dung & 24h đâu n (\%) & Ngày 5 n (\%) & Ra viện n (\%) \\
\hline Kê chân cao $30^{\circ}$ trên giàn & $115(69,3)$ & $123(74,1)$ & 0 \\
\hline
\end{tabular}




\begin{tabular}{|c|c|c|c|}
\hline Đặt bàn chân vuông góc & $55(33,1)$ & $117(70,5)$ & 0 \\
\hline Tập nhẹ các ngón chân & $70(42,2)$ & $164(98,8)$ & $164(98,8)$ \\
\hline
\end{tabular}

Trong 24 giờ đầu sau mố NBđược kê chân cao $30^{\circ}$ trên giàn chiếm 69,3\%) đặt bàn chân vuông góc $(33,1 \%)$, tập nhẹ các ngón chân $(42,2 \%)$. Thời điểm ra viện phần lớn NBtập nhẹ các ngón chân $(98,8 \%)$.

Bảng 3.6. Tai biến, biến chứng vêt mổ

\begin{tabular}{|c|c|c|c|}
\hline Nội dung & 24h đâu n (\%) & Ngày 5 n (\%) & Ra viện n (\%) \\
\hline Chảy máu vêtt mố & $6(3,6)$ & $1(0,6)$ & 0 \\
\hline Nhiêm khuấn(NK)vết mố & $0(100)$ & $11(6,6)$ & 0 \\
\hline NK hố hấp & $0(100)$ & $1(0,6)$ & 0 \\
\hline NK tiết niệu & $0(100)$ & $2(1,2)$ & 0 \\
\hline
\end{tabular}

Tai biến trong 24 giờ đầu sau mố có $3,6 \%$ NB chảy máu vết mô. Sau 3 ngày, NK vết mố là $6,6 \%$; NK hô hấp là $0,6 \%$, NK tiết niệu là $1,2 \%$, chảy máu vết mổ là $0,6 \%$. Thời điểm ra viện $100 \%$ NB ổn định.

Bảng 3.7. Chế độ dinh dưỡng

\begin{tabular}{|c|c|c|c|}
\hline Nội dung & 24h đâu n (\%) & Ngày 5 n (\%) & Ra viện n (\%) \\
\hline Không ăn & $2(1,2)$ & $0(100)$ & $0(100)$ \\
\hline Truyền dịch & $162(97,6)$ & $1(0,6)$ & $0(100)$ \\
\hline Än nhè, cháo, sữa & $35(21,1)$ & $13(7,8)$ & $5(3,0)$ \\
\hline Än bình thường & $125(75,3)$ & $155(93,4)$ & $161(97,0)$ \\
\hline
\end{tabular}

Trong 24 giờ đầu sau mố NBđược truyền dịch là 97,6\%, ăn nhe cháo sữa $(21,1 \%)$, ăn bình thường $(75,3 \%)$. Thời điểm ra viện phần lớn NBăn uống bình thường $(97,0 \%)$.

Bảng 3.8. Tâm lý NBsau mố

\begin{tabular}{|c|c|c|c|}
\hline Nội dung & 24h đâu n (\%) & Ngày 5 n (\%) & Ra viện n (\%) \\
\hline Yền tâm & $9(5,4)$ & $98(59,0)$ & $148(89,1)$ \\
\hline Lo lắng & $157(94,6)$ & $68(41,0)$ & $18(10,8)$ \\
\hline
\end{tabular}

Trong 24 giờ đầu sau mố,NBlo lắng chiếm tỷ lệ cao $(94,6 \%)$. Sau 3 ngày còn $41,0 \%$. Thời điểm ra viện NBcó tâm lý yên tâm là $89,1 \%$.

Bảng 3.9. Kết quả tư vấn, giáo dục sức khoẻ cho NBtrong và khi ra viện

\begin{tabular}{|c|c|c|c|}
\hline Bang 3.9. Kêti dung & 24h đâu n (\%) & Ngày 5 n (\%) & Ra viện n (\%) \\
\hline Hướng dần(HD) tập vận động & $68(41,0)$ & $166(100)$ & $153(92,2)$ \\
\hline HD vệ sinh cá nhân, giữ khô̂ vết mố & $149(89,8)$ & $166(100)$ & $166(100)$ \\
\hline HD chế độ ăn & $152(91,6)$ & $166(100)$ & $151(90,9)$ \\
\hline HD kiến thức, biến chứng sau mố & $138(83,1)$ & $166(100)$ & $151(90,9)$ \\
\hline
\end{tabular}

Đa phần NB trong 24 giờ đầu sau mổ được HDchế độ ăn chiếm tỷ lệ cao nhất $91,6 \%$, giữ vệ sinh và giữ khô vết mổ $89,8 \%, H D$ theo dõi phát hiện biến chứng sau mổ $83,1 \%$, vận động sớm là $41,0 \%$. Thời điểm ra viện HD theo dõi phát hiện biến chứng sau mổ là $90,9 \%$, vận động sớm $(92,2 \%)$, giữ vệ sinh và giữ khô vêt mổ $(82,5 \%)$

\begin{tabular}{|c|c|c|c|}
\hline $\begin{array}{l}\text { Tình trang } \\
\text { sau phấu } \\
\text { thuật }\end{array}$ & $\begin{array}{c}\text { 24h đâu } \\
\text { n (\%) }\end{array}$ & $\begin{array}{l}\text { Ngày } 5 \\
\text { n (\%) }\end{array}$ & $\begin{array}{c}\text { Ra viện } \\
\text { n (\%) }\end{array}$ \\
\hline Tốt & $160(96,3)$ & $147(88,5)$ & $155(93,3)$ \\
\hline Khá & $6(3,7)$ & \begin{tabular}{|l|}
$19(11,5)$ \\
\end{tabular} & $11(6,6)$ \\
\hline
\end{tabular}

Tại thời điêm 24 h sau mố có $96,3 \%$ NBcó tình trạng phẫu thuật tốt và chỉ có 3,7\% NBcó tình trạng khá. Sau 3 ngày tỷ lệ NBcó tình trạng phẫu thuật khá là $11,5 \%$. Thời điểm ra viên phần lớn tình trang sau phấu thuật NBtốt là 93,3\%. Không có trường hợp nào có tình trạng xấu sau phẫu thuật

\section{BÀN LUÂ̂N}

Tại thời điểm 24h đầu sau mổ, 100\% NB tỉnh táo tiếp xúc tốt, sau 3 ngày và lúc ra viện $100 \%$ NB hoàn toàn tỉnh táo. Các chỉ số mạch, nhiêt độ, huyết áp, nhịp thở (dấu hiệu sinh tồn) của một số NB cao hơn giới hạn bình thường tuy nhiên sau 3 ngày và khi ra viện các chỉ số đa phần đã trở về bình thường.

Đau sau phẫu thuật là một loại đau cấp tính, trong 24 giờ đầu sau mổ toàn bộ NB đều đau, trong đó đau vừa chiếm $68,7 \%$, Một số NB đau nhiều, cơ thể phản ứng tự nhiên dẫn tới tình trạng mạch, huyết áp, nhịp thở, nhiệt tăng nhe cao hơn chỉ số bình thường. Những ngày sau và̀ lúc ra viện thì các chỉ số trở về bình thường do vết thương đang tiến triển tốt,ổn định dần.

Phần lớn vết mổ của NB trong 24 giờ đầu sau mổ khô chiếm 94,6\% sưng nề đỏ là $92,2 \%$, chảy rỉ máu là $3,6 \%$ Thời điểm ra viên vết mổ khô bình thường chiếm tỷ lệ $98,2 \%$ chỉ còn $1,8 \%$ NB còn hơi sưng nề tại vết mô. Có sự khác biệt với 
nghiên cứu của Nguyễn Gia Dũng (2019) có $58,6 \%$ NB có tình trạng vết mổ nề đỏ, $8,6 \%$ NB có chảy dịch và $32,8 \%$ NB có tình trạng vết mổ tốt[5]. Nguyên nhân là trong $24 \mathrm{~h}$ đầu sau mổ do cơ chế tổn thương cớ, mạch máu và thần kinh nên phần lớn vết mố sưng nề đỏ là hoàn toàn bình thường và sẽ giảm dần và hết vào những ngày sau, tuy nhiên vào ngày thứ $3-5$ sau mổ mà vẫn còn sưng nề đỏ kèm theo tiết dịch, rỉ máu hay trợt da thì có nghĩa là có dấu hiệu của NK nông tại vết mổ, khi toàn thân có dấu hiệu nhiễm trùng rõ như sốt, bạch cầu tăng cao là nhiễm khuẩn sâu trong tổ chức[3].

Nhiễm khuẩn vết mổ về lâm sàng được định nghĩa là khi có bằng chứng xuất hiện chảy mủ với dấu hiệu tai chỗ sung đỏ, vêt thương trở lên cứng và đau, dế phá võ hoặc toác, bục [2], [3]. Trong nghiên cứu của chúng tôi NB có dấu hiệu NK vết mổ nông vào ngày thứ 3 là sưng nề đỏ và tiết dịch thấm băng, chiếm tỷ lệ $6,6 \%$. Kết quả này có điểm đương đồng so với kết quả nghiên cứu của Nguyễn Gia Dũng (2019) [5]. Điều này hoàn toàn phù hợp với quá trình diến biến của bệnh.

Vềchế độ dinh dưỡng trong 24 giờ đầu sau mổ,NBđược truyền dịch chiếm tỷ lệ $97,6 \%$, ăn nhẹ cháo sữa chiếm tỷ lệ $(21,1 \%)$. Sau 3 ngày và ra viện phần lớn NBăn uống bình thường $97,0 \%$. Thường thì sau khi mổ NB vẫn được truyền dịch chủ yếu nhằm mục đích đào thải thuốc mế, còn vẫn được ăn uống nhẹ hoặc cháo sữa khi tỉnh vì các cuộc phẫu thuật này không liên quan đến đường tiêu hóa, còn các phẫu thuật bụng chỉ được ăn khi có trung tiện, thậm chí mây ngày sau tùy vào các tạng bị phấu thuật.

Ngủ đủ giấc là điều rất quan trọng đối với những NB phẫu thuật chỉnh hình nhẳm phục hồi và sửa chữa sức khỏe tâm sinh lý, đặc biệt nó ảnh hưởng đến quá trình lành vết thương và rút ngắn thời gian hồi phục. Kết quả nghiên cứu cho thây trong 24 giờ đầu sau mổ NB ngủ được bình thường (46,4\%); Sau 3 ngày NB ngủ được là 80,1\%; Thới điểm ra viện NB ngủ được là 93,3\% (bảng 4). Lý giải điều này NB đã được sử dụng thuốc giảm đau an thần theo y lệnh để đảm bảo giấc ngủ.

Tư vấn, giáo dục sức khoẻ cho NBtrước, trong và khi ra viện là một trong những hoạt động chính của người $\mathrm{D} \oplus$ trong quá trình chăm sóc nhằm nâng cao hiệu quả trong điều trị. Theo kết quả nghiên cứu của chúng tôi tại thời điểm 24 giờ đâu sau mổ phần lớn NB được $\mathrm{HD}$ chế độ ăn chiếm tỷ lệ cao nhất $91,6 \%$, giữ vệ sinh và giữ khô vết mổ $89,8 \%$. Sau 3 ngày 100\% NB được hướng dẫn. Thời điểm ra viện HD theo dõi phát hiện biến chứng sau mổ chiếm tỷ lệ $90,9 \%$, vận động sớm là $92,2 \%$, giữ khô vết mổ $82,5 \%$, HD chế độ ăn chiếm tỷ lệ 78,9\% (bảng 9). Kết quả này có sự tương đồng với kết quả nghiên cứ của Đào Đức Hạnh (2015) kết quả cao nhất đạt $93,3 \%$, thấp nhất là $92,6 \%$, trung bình là $90,7 \%[6]$. Nghiên cứu của Trần Tú Anh (2018) tỷ lệ hộ sinh thực hiện không đồng đều và không hoạt động nào được thực hiện đủ $100 \%$, trong đó hộ sinh thường chỉ chú trọng những tư vấn có liên quan đến vấn đề chuyên môn như: $H D$ chăm sóc vết mổ đạt $94 \%$; Tư vấn các dấu hiệu bất thường $80 \%$ và kém nhất là hướng dẫn chế độ ăn uống $68 \%[1]$. Lý giải điều này, vì thời điểm sau mổ và trong suốt quá trình nằm viện $\mathrm{NB}$ luôn được các điều dưỡng chăm sóc, bác sĩ giải thích động viên về các chế độ và cung cấp kiến thức cho NB và người nhà bệnh nhân kết hợp tốt để nâng cao hiệu quả chăm sóc tôt nhất.

Kết quả quá trình điều trị, chăm sóc NBtrong nghiên cứu, phần lớn NB đạt kết quả chăm sóc điêu trị tốt. Không có trường hợp nào có tình trạng xấu sau phẩu thuật (bảng 10). Kết quả này có sự tương đồng với nghiên cứu của Ta Đức Chung (2019) tại BV TW Quân đội 108và cao hơn kết quả nghiên cứu của Nguyễn Gia Dũng (2019) tại BV Đức Giang[4][5]. Lý giải cho kết quả chăm sóc này là do ĐD thực hiện tốt và tương đối đầy đủ chức trách nhiệm vụ của $D \oplus$ ngoại khoa, theo dõi chăm sóc và hướng dẫn NB sau mổ đúng quy trình đã được quy định tại Thông tư 07/2011/TT-BYT giúp NB hồi phục nhanh chóng.

\section{KẾT LUẦN}

Kết quả chăm sóc NB sau mổ, tại thời điểm 24 có $96,3 \%$ bệnh nhân có tình trạng phẫu thuật tốt và chỉ có $3,7 \%$ NB có tình trạng khá. Sau 3 ngày, tỷ lệ NBcó tình trạng phẫu thuật khá là $11,5 \%$. Thời điểm ra viện phần lớn tình trạng sau phẫu thuật NB tốt là 93,3\%. Không có trường hợp nào có tình trạng xấu sau phẫu thuật.

\section{TÀI LIỆU THAM KHẢO}

1. Trần Thì Tú Anh (2018), Thực trang thực hiên quy trình chăm sóc sản phụ, sớ sinh sau mổ lấy thai và đánh giá của người bệnh về chất lượng dịch vụ tại khoa Sản Bệnh lý - Bệnh viện Phụ sản trung ương năm 2018, Luận văn Thạc sỹ quản lý bênh viên, Trường Đai họ Y Y tế công cộng.

2. Bộ Y tể (2011), Hướng dẫn công tác điều dưỡng về chăm sóc người bệnh trong bệnh viện ( Kèm theo Thông tư số 07/2011/TT-BYT), chủ biên.

3. Bộ Y tế (2012), Hướng dẫn phòng ngửa nhiễm khuẩn vết mổ (Kèm theo Quyết định số: 3671/QĐBYT), chủ biên. 
4. Tá Đức Chung (2019), Đánh giá kết quả chăm sóc người bệnh chấn thương sau phẫu thuật tại bênh viên trung ương quân đội 108, Luận văn Thạc sỹ Điều dưỡng, Trường Đaai học Thăng Long.

5. Nguyễn Gia Dũng (2019), Đ̇ặc điểm, chăm sóc người bệnh phẫu thuật gãy xương chi dưới và các yếu tố liền quan đến chăm sóc tại khoa ngoại bệnh viện Đức Giang, Luận văn Thạc sỹ Điều dưỡng, Trường Đại học Thăng Long.

6. Đào Đức Hạnh (2015), Thức trang công tác chăm sóc điều dưỡng người bệnh cần chăm sóc cấp I tai viện chấn thương chỉnh hình, bệnh viên trung ương quân đội 108 năm 2015, Luận vằn Thạc sỹ quản lý bệnh viện, Đại học Y tế công cộng.

\section{NHẬN XÉT ĐĂC ĐIỂM SIÊU ÂM VÀ GIẢI PHẪU BÊNH CỦA BƯớU NHÂN TUYẾN GIÁP TẠI BỆNH VIỆN ĐA KHOA TỈNH THÁI BİNH}

\section{TÓM TẮT.}

Muc tiêu: Nhân xét đặc điểm siêu âm và giải phẫu buệnh của bướu nhân tưyến giáp tại bệnh viện đa khoa tỉnh Thái Bình. Phương pháp: nghiển cứu tiến cứu mô tả cắt ngang. Nghiên cứu được tiến hành trên 176 bệnh nhân có bướu nhân tuyến giáp được chọc hút kim nhỏ dưới hướng dẫn của siêu âm tại bệnh viện đa khoa tỉnh Thái Bình. Kết quả: Kích thước trung bình của các nhân u được chọc hút là 10,5 \pm $7,2 \mathrm{~mm}$. Các bướu nhân có bờ đều, ranh giới rõ chiếm tỷ lệ cao $(85,2 \%)$, bờ không đều chiếm tỷ lệ thấp. Phần lớn các nhân giáp là hốn hợp âm $(51,7 \%)$, sau đó là giảm âm (32,4\%), các nhân tăng âm hoặc đồng âm chiếm tỷ lệ thấp. Các nhân giáp không có hiện tượng vôi hóa chiếm tỷ lệ $68,8 \%$, các nhân có vi vôi hóa chiếm tỷ lệ $9,0 \%$. Chẩn đoán mô bệnh học: bướu giáp keo lành chiếm tỷ lệ 70,9\%, UTBM thể nhú $19,4 \%$, u tuyến nang $9,7 \%$. Các nhân giáp ác tính thường có kích thước nhỏ $<10 \mathrm{~mm}(66,7 \%)$, là nhân giảm âm $(66,6 \%)$ và có vi vôi hóa $(66,7 \%)$.

\section{SUMMARY}

\section{A REVIEW THE CHARATERISTICS OF UNTRASOUND AND PATHOLOGY OF THE THYROID NODULES AT THAIBINH GENERAL HOSPITAL}

Objective: To review the characteristics of ultrasound and pathology of the thyroid nodules at Thai Binh General Hospital. Methods: cross-sectional descriptive research. The study was conducted on 176 patients with thyroid neoplasm using FNA with ultrasound guidance at Thai Binh General Hospital. Result: The average size of the neoplasms was 10.5 $\pm 7.2 \mathrm{~mm}$. Neoplasms have equal and clear border accounts for a high rate (85.2\%). Most of the turmors is mixed echo $(51.7 \%)$, followed by hypoechoic $(32.4 \%)$. The turmors without calcification phenomenon were $68.8 \%$ and microcalcifications were 9.0\%. Diagnosis of histopathology: goiter: $70.9 \%$, adenoma $9.7 \%$, papillary carcinoma $19.4 \%$. Malignant

${ }^{1}$ Trường Đại hoc Y Dược Thái Bình

Chịu trách nhiệm chính: Trần Mạnh Hà

Email: manhha.tbump@gmail.com

Ngày nhận bài: 13.8.2021

Ngày phản biên khoa học: 4.10 .2021

Ngày duyệt bài: 15.10.2021

\section{Trần Mạnh Hà ${ }^{1}$, Nguyễn Thị Thanh Hà ${ }^{1}$}

thyroid nodules usually have a small size $<10 \mathrm{~mm}$ $(66.7 \%)$, are hypoechoic $(66.6 \%)$ and have microcalcification (66.7\%).

\section{I. ĐẶT VẤN ĐỀ}

Tuyến giáp là một tuyến nội tiết quan trọng của cơ thể, có vai trò điều hòa hoạt động của các cơ quan, thúc đẩy sự phát triển của tế bào và kiểm soát sử dụng năng lượng. Bệnh lí tuyến giáp rất đa dạng nhưng biểu hiện lâm sàng muộn, triệu chứng không rầm rộ nên dễ bị bỏ sót. Hơn nữa, một số tổn thương có kích thước nhỏ hoăc nằm ở vị trí khó tiếp cận nên ít nhiêu gây khó khăn cho chẩn đoán. Hiện nay có rất nhiều loại xét nghiệm được sử dụng trong chẩn đoán bướu nhân tuyến giáp, trong đó siêu âm và chọc hút kim nhỏ được coi là những phương tiện chẩn đoán rất hiệu quả giúp phát hiện sớm và tìm hiểu bản chất của bướu giáp. Việc phát hiện các nhân giáp có đường kính $<1 \mathrm{~cm}$ hoặc ở vị trí sâu trên lâm sàng là rất khó khăn nhưng nếu áp dụng siêu âm vào chẩn đoán thì tỉ lệ phát hiện bướu nhân tuyến giáp tăng lên khoảng 10 lần so với khám lâm sàng, [1],[2],[3]. Tuy nhiên, siêu âm vẫn chưa đủ để nói lên tổn thương đó là ác hay lành tính. Chọc hút kim nhỏ là kỹ thuật đơn giản nhưng rất giá trị trong việc xác định bản chất một nhân tuyến giáp. Tuy nhiên, chọc hút kim nhỏ có thể bỏ sót các tổn thương nhỏ, đa thương tổn hoặc ở vị trí khó tiếp cận. Việc kết hợp siêu âm và chọc hút kim nhỏ sẽ bổ sung cho nhau, phần nào tránh được các hạn chế của mỗi phương pháp. Vì vậy, chúng tôi tiển hành nghiên cứu này với mục tiêu: Nhận xét đặc điểm siêu âm và giải phẫu bệnh của bướu nhẩn tuyến giáp tại bệnh viện đa khoa tỉnh Thái Bình năm 2019.

\section{II. ĐỐI TƯỢNG VÀ PHƯƠNG PHÁP NGHIÊN CỨU \\ 1. Đối tượng nghiên cứu}

2.1.1. Đối tượng nghiên cứu. Nghiên cứu gồm 176 bệnh nhân có bướu nhân tuyến giáp được khám và điều trị tại các khoa Nội tiết, Ung 